\title{
The Historical Change from Suffixal to Prefixal Reduplication in Hausa Pluractional Verbs
}

\author{
PAUL NEWMAN
}

Hausa has a derivational process by which "pluractional" verbs (often termed "intensives") are formed from simple verb stems by reduplication. These verbs indicate multiple, iterative, frequentative, distributive, or extensive actions (Al-Hassan 1983, Frajzyngier 1965, Gouffé 1975, Pawlak 1975). ${ }^{1}$ Historically, the process consisted in reduplicating the two right-most syllables of the verb, with concomitant deletion of the original stem-final vowel. This is illustrated in (1), where the reduplicant is underlined. ${ }^{2}$

$\begin{array}{llll}\text { *yagala } & \Rightarrow & \text { yagalgàlaa } & \text { 'tear to shreds' } \\ \text { *kucina } & \Rightarrow & \text { kucincìnaa } & \text { 'break pieces off' } \\ \text { *takare } & \Rightarrow & \text { takarkàree } & \text { 'strive hard' }\end{array}$

Synchronically, on the other hand, most verbs form pluractionals by reduplicating the initial CVC- of the stem, where the $\mathrm{C}_{2}$ assimilates to the following abutting consonant or undergoes rhotacization, e.g.

\begin{tabular}{|c|c|c|c|}
\hline tunàa & $\Rightarrow$ & tuntùnaa & 'remind' \\
\hline gaskàtaa & $\Rightarrow$ & $\overline{g a s}$ gaskàtaa & 'verify' \\
\hline kaamàa & $\Rightarrow$ & kankàamaa [kankàamaa] & 'catch'3 \\
\hline bugàa & $\Rightarrow$ & $\underline{b u b} b \grave{u} g a a$ & 'beat' \\
\hline raatàyaa & $\Rightarrow$ & rarraatàyaa & 'hang' \\
\hline fìta & $\Rightarrow$ & firfita & 'go out'. \\
\hline
\end{tabular}

This paper describes the interesting diachronic development whereby the rule of two-syllable reduplication to the right was replaced by CVCreduplication to the left.

* This paper was originally presented at the Conference on the Theory and Practice of Historical Linguistics, University of Chicago, 27 April 1988. The final version was completed while I was a Fellow at the Center for Advanced Study in the Behavioral Sciences, Stanford, California. Financial support provided by the National Science Foundation (grant \#BNS8700864) is gratefully acknowledged. Research on Hausa pluractionals that formed the basis of this paper was carried out with the assistance of Dr. Sammani Sani and Dr. Ismail Junaidu, to both of whom I express my sincere thanks. I would also like to thank Larry Hyman for useful comments and suggestions. 


\section{EVIDENCE FOR ORIGINAL SUFFIXAL REDUPLICATION}

1.1. Hausa has a considerable number of "frozen pluractionals", i.e. verbs that are reduplicated in shape, but for which a non-reduplicated form generally does not exist, e.g.

babbàkaa
sunsùnaa
gatsaltsàlaa

'burn, roast' (cf. Proto-West Chadic *baku) 'smell (cf. Proto-Chadic*sun)

'scamp (work)' (cf. ideophone gàtsàl-gàtsàl)

With many, but not all, of the frozen forms, a pluractional meaning is still identifiable, as in the following:

gir̃gizaa 'shake'; sussùkaa 'thresh'; furfùraa 'barter;

gutsuntsùnaa 'break into fragments'; rafaffàkaa 'walk hesitantly';

badandàmaa 'flounder'; daabilbilaa 'trample ground'

With disyllabic CVCV stems, the direction of the reduplication is not evident; that is, a word such as furfuraa, for example, could equally come from *fur(a)fura or *furfura. By contrast, with trisyllabic stems, the nature of the reduplication is clear. In the case of a word such as rafaffakaa $(<$ * rafaka), suffixal reduplication is the only possibility: CVC-prefixation would have resulted in the non-occurring ??rarrafaka. When one looks at frozen pluractionals of three syllable stems, one finds that all of them, without exception, manifest suffixal reduplication. Since the now frozen forms reflect what earlier must have been a productive process, they provide strong evidence that the original pluractional formation was two-syllable reduplication to the right.

1.2. Synchronically, most simple verb stems form their pluractionals by prefixal CVC-reduplication; but not all. Some trisyllabic verbs still use suffixal reduplication, e.g.

$\begin{array}{llll}\begin{array}{l}\text { dàaguràa } \\ \text { tàfasà }\end{array} & \Rightarrow & \text { dàagùrguràa } & \text { 'gnaw' } \\ \text { hadìyee } & \Rightarrow & \text { tàfàrfasà } & \text { 'boil' } \\ \text { rikitaa } & \Rightarrow & \text { hadìidìyee } & \text { 'swallow' }\end{array}$

In addition, a small number of CVCCV verbs with a syllable final rhotic or glide also form their pluractionals by reduplication to the right, building on a trisyllabic base created by inserting an epenthetic vowel between the abutting consonants, e.g. 


\begin{tabular}{|c|c|c|c|c|}
\hline muरे & $d(e)$ & $\Rightarrow$ & 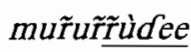 & 'twist' \\
\hline$k a$ & (*girika) & & girirrika & "put pots on the fir \\
\hline hàifa & (*hayafa) & $\Rightarrow$ & hàyàyyafàa & 'give birth, beget' \\
\hline karyàa & $(*$ karaya $)$ & 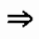 & karairàyaa & 'break, snap' \\
\hline
\end{tabular}

The restricted nature of the suffixal reduplicative formation suggests strongly that this is an archaism reflecting the same historically original pattern for trisyllabic (and CVCCV) stems already observed with the frozen pluractionals.

1.3. While the direction of reduplication with the disyllabic stems is not directly observable, the overall facts indicate that two-syllable suffixal reduplication was the historically original pattern here also. First, it has been shown (Newman 1986a) that the general process in nominal reduplication, as reflected in lexically frozen forms, was two-syllable reduplication to the right. Second, it is a well-known fact of Hausa that all of the processes of reduplication used in noun pluralization involve reduplication to the right. Finally, on grounds of general regularity and simplicity, there is no reason to assume that early Hausa had two entirely distinct morphological rules for producing pluractionals - a prefixal rule for disyllabic stems and a suffixal rule for trisyllabic stems - when the occurring forms can all be accounted for by a single process. One is thus justified in concluding that at an earlier period, two-syllable suffixal reduplication was the pluractional verb formation rule for all verb stems regardless of their canonical syllabic shape.

\section{THE HISTORICAL DEVELOPMENT}

2.1. Now that we have established the original suffixal nature of the pluractional rule, we can describe the developments leading to the presentday prefixal reduplicative formation. The initial link in the chain of events was a general morphological rule of stem-final vowel dropping whenever suffixes were added. This rule, which is still operative in present-day Hausa (Newman 1986b), applied (and still applies) to pluractional reduplication to the right, e.g.

$$
\begin{aligned}
& \text { *yagala } \Rightarrow \text { *yagal(a)-gala } \rightarrow \text { yagalgàlaa 'tear to shreds' } \\
& \text { *bad(a) } \Rightarrow{ }^{*} b a d(a) \text {-bada } \rightarrow \text { baŕbàdaa } \text { 'sprinkle' }
\end{aligned}
$$

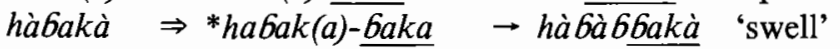

The syllable of the stem immediately preceding the reduplicant was then subject to the many phonological processes that systematically affect Hausa 
segments in closed syllables. These include (a) rhotacization of syllablefinal coronal obstruents, e.g. *gadgadaa $\rightarrow$ gar̃gadaa 'rutted road'; (b) assimilation in position of articulation of syllable final nasals, e.g. *jàarùmtakàa $\rightarrow$ jàar̃ùntakàa 'bravery'; (c) complete assimilation of certain syllable-final consonants, e.g. *zàafzaafaa $\rightarrow$ zàzzaafaa 'very hot'; and (d) shortening of all long vowels plus lowering of mid vowels in closed syllables, e.g. *saaboon gidaan àbookiinsà $\rightarrow$ saaban gidan àbookinsà 'his friend's new house' (lit. 'new-of/house-of/friend-of-his). The application of these processes in pluractionals is illustrated in (8).

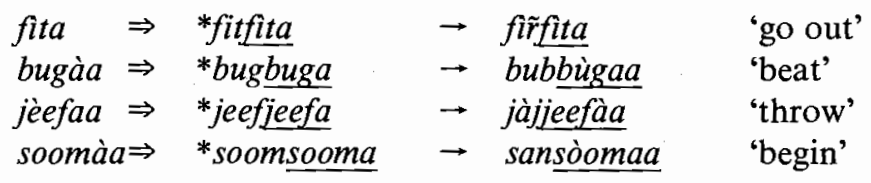

With disyllabic CVCV stems, the result was that the reduplicant in the pluractional construction manifested the full form of the underlying verb stem while the original stem was phonologically greatly deformed. Given simple/pluractional pairs such as bugàa/bubbùgaa and soomàa/sansòomaa, it was only natural for the pluractionals to be morphologically reanalyzed so that the stem and the reduplicant were reversed, e.g.

\begin{tabular}{|c|c|c|}
\hline bubbùggaa & $>$ & bubbùgaa \\
\hline *fîrfita & & fî́rfita \\
\hline * sansòomaa & & san \\
\hline jàjjeefàc & & jàjjeef \\
\hline
\end{tabular}

Note that in the development illustrated in (9), a significant historical change took place in the grammar without, at first, any change in the form of the pluractionals themselves. The result of the morphological reanalysis of the surface form was that a CVC-reduplicant was created where originally it didn't exist. Once pluractional verbs such as sansòmaa were interpreted as being derived by an active prefixal rule, it was only a small step for the rule to be extended to trisyllabic stems. With certain words, the newer and older forms have continued to coexist; with other words, including many loanwords, only the new prefixal form is used.

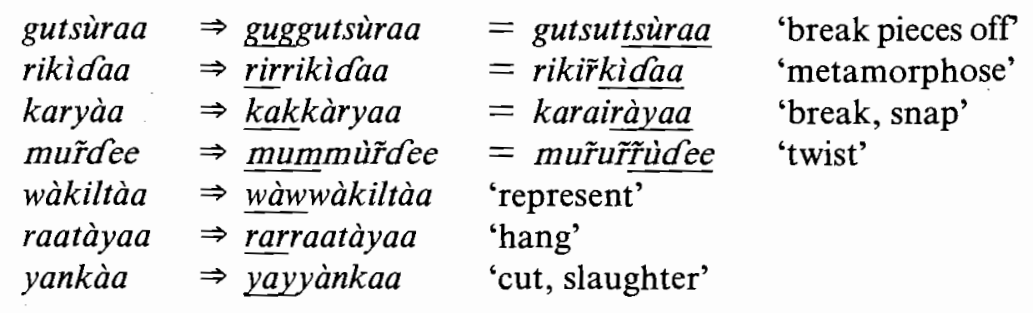


Where the two pluractional forms coexist, the one with reduplication to the right is generally felt to be semantically stronger and more intense than the one with the reduplicative CVC-prefix. In a few cases doublets have diverged and taken on slightly different meanings, e.g.

a. hàifaa 'give birth' $\Rightarrow$ (i) hàhhaifàa 'give birth many times' (as in 'She bore many children.') or (ii) hàyàyyafàa 'generate, proliferate' (as in 'The student rebellion precipitated widespread unrest.')

b. Kirgàa $(<* \text { Kidga })^{4}$ 'count' $\Rightarrow$ (i) KikKîrgaa 'count several times' or (ii) Kididdigaa 'calculate'.

Having emerged as a synchronically productive pluractional formation, the CVC-prefix has become available for use with frozen pluractionals, many of which had undergone semantic erosion and thereby had lost their earlier distinctively pluractional connotations.

$\begin{array}{llll}\text { jagwalgwàlaa } & \left(<*_{\text {jagwala })}\right. & \Rightarrow \text { jajjagwalgwàlaa } & \text { 'make a mess' } \\ \text { cukwiikwìaa } & \left(<*^{*} \text { cikuya }\right)^{5} & \Rightarrow \text { cuccukwiikwiyaa } & \text { 'tangle up' } \\ \text { babbàkaa } & \left(<*_{\text {baka })}\right. & \Rightarrow \text { babbabbàkaa } & \text { 'burn, roast' } \\ \text { tsantsàmee } & \left(*^{*} \text { tsame }\right) & \Rightarrow \text { tsattsantsàmee } & \text { 'wash lightly' }\end{array}$

The productiveness of the new CVC-prefix is strikingly illustrated by its use along with synchronically generated reduplicative suffixes, thereby resulting in semantically even stronger "hyperpluractionals", 6 e.g.

$$
\begin{aligned}
& \text { tàfasà } \quad \Rightarrow \text { tàfàrfasà } \quad \Rightarrow \text { tàttàfàrãfasà } \\
& \text { zabàkaa } \Rightarrow \text { zabab́ăkaa } \Rightarrow \text { zazzababbàkaa 'boil, cook' } \\
& \text { makàlaa } \Rightarrow \text { makalkàlaa } \Rightarrow \text { mammakalkàlaa 'lodge, stick in' }
\end{aligned}
$$

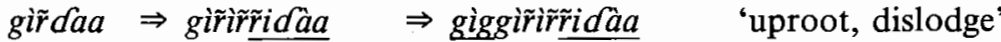

$$
\begin{aligned}
& \text { tartsèe } \Rightarrow \text { tararràtsee } \Rightarrow \text { tattararràtsee } \quad \text { 'smash' }
\end{aligned}
$$

2.2. The CVC-reduplicative prefix is now undergoing a further development which is still in progress. Instead of copying the initial $C_{1} V_{2}-$ of the stem, a new rule is emerging in which $C_{1} V G$ - is prefixed, where $G$ serves to form a geminate with the following consonant. In the original two-syllable suffixal reduplication, geminates commonly occurred as a result of the complete assimilation of a stem-final consonant to the following abutting consonant, e.g.

$\begin{array}{lll}\text { *wajagjaga } & \rightarrow \text { wajajjàgaa } & \text { 'shake, scatter' } \\ \text { *gidibdiba } & \rightarrow \text { gididdibaa } & \text { 'slice up' } \\ \text { *bakbaka } & \rightarrow \text { babbàkaa } & \text { 'burn, roast' }\end{array}$


The same complete assimilation rule also produced geminates in the new $\mathrm{C}_{1} \mathrm{VC}_{2}$-pluractional forms.

$\begin{array}{lll}\text { *bugbuga } & \rightarrow \text { bubbùgaa } & \text { 'beat' } \\ \text { *tooktookare } & \rightarrow \text { tattookàree } & \text { 'prop against, block' }\end{array}$

Now, however, the gemination is becoming morphologized, so that geminates are the norm in prefixal pluractional verbs (although not absolutely required) even in cases where assimilation is not phonologically required and would not normally take place, e.g.

\begin{tabular}{|c|c|c|}
\hline kiraa & $\Rightarrow$ kikkiraa & $\begin{array}{l}\text { 'call' (cf. girkàa 'cook', without } \\
\text { gemination) }\end{array}$ \\
\hline 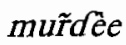 & $\Rightarrow$ mummùr $\tilde{r} d e e$ & 'twist' (cf. gàrrmaa 'hoe') \\
\hline bulloo & $\Rightarrow \overline{6 u b 6}$ ulloo & 'appear suddenly' (cf. sulbii 'slippery') \\
\hline kaamàa & $\Rightarrow \overline{k a k} k a ̀ a m a a$ & 'catch' = kankàamaa \\
\hline fita & $\Rightarrow$ fiffita & go out' $=$ firrfita \\
\hline
\end{tabular}

In this connection, one can contrast the form of frozen pluractionals, where gemination is not evidenced, with forms resulting from the new productive pluractional prefix, where gemination is strongly preferred. ${ }^{7}$

$$
\begin{aligned}
& \text { sunsùnaa }(<* \text { suna }) \Rightarrow \text { sussunsùnaa 'smell' } \\
& \text { gir̃ gizaa } \quad(<* \text { giza }) \Rightarrow \text { giggir̃gizaa 'shake, upset' } \\
& \text { gwìigwiyàa }(=/ \text { gùyguyàa })(<* \text { guya }) \Rightarrow \text { gùggwìgwiyàa 'gnaw' } \\
& \text { mulmùlaa }\left(<{ }^{*} \text { mula }\right) \Rightarrow \text { mummulmùlaa 'knead' }
\end{aligned}
$$

Thus again we find a commonly occurring surface form - in this case gemination - being reinterpreted in morphological terms as a $\mathrm{C}_{1}$ VG-prefix and thus being extended to forms where phonologically it originally did not apply. ${ }^{8}$

\section{SUMMARY AND CONCLUSION}

At an earlier period in the Hausa language, all pluractional verbs were derived from simple stems by reduplicating the two right-most syllables. Starting with disyllabic stems, where the direction of the reduplication was not evident in the resultant surface form, pluractional verbs were reinterpreted as containing a reduplicative $C_{1} V_{2}$-prefix. This rule of prefixal reduplication spread to trisyllabic stems and ultimately became the dominant formation that one finds today. The most recent development, which is still in an incipient stage, is the change of the $\mathrm{C}_{1} \mathrm{VC}_{2}$-prefix into a $\mathrm{C}_{1} \mathrm{VG}$ - 
prefix, i.e. the syllable-final consonant in the reduplicant, which previously had copied the second consonant of the stem, is being replaced by an underspecified segment that forms a geminate with the following abutting consonant.

This paper presents a clear case illustrating how the reinterpretation of surface phonological outputs can lead historically to the reformulation of morphological word-formation rules. Along with Faraclas and Williamson (1984), it is one of the first papers to treat reduplication in African languages from a diachronic perspective.

\section{NOTES}

1. According to Parsons (1981:206), these verbs express "plurality of action, i.e. one actor, or a number of actors doing the same thing to a number of objects, either simultaneously or in succession; or a number of actors doing the same thing to the same object severally and/or in succession; or else one actor doing the same thing to the same object several times over.... With intransitive verbs it adds a notion either of multitude and/or succession,.... or sometimes of distribution in space...." (underline his). The term "pluractional", which has now been adopted by a number of Chadicists, was first proposed by Newman $(1980: 13 \mathrm{n})$. 2. Transcription and conventions: The symbols $c$ and $j$ represent the affricates $/ \mathscr{c} /$ and $/ J / ; \mathrm{sh}=/ \check{s} / ;$ ts is an ejective sibilant, in some dialects pronounced as an alveolar or palatoalveolar affricate; $\tilde{r}$ is a roll or tap, which contrasts with the unmarked postalveolar flap $r$. Geminates of consonants transcribed as digraphs are indicated by doubling the initial letter only, e.g. $t t s=$ geminate $t s ; s s h=$ geminate $s h$. Long vowels are indicated by double letters. Low tone is indicated by a grave accent, e.g. $\grave{a}$, high tone is unmarked. Verbs are given in their standard dictionary citation form; presumed earlier forms are transcribed without tone or final vowel length indicated. The asterisk * indicates hypothetical historical or synchronically intermediate forms while ?? indicates synchronically unacceptable or questionable items. The double arrow $\Rightarrow$ is used for morphological word formation rules while the single arrow $\rightarrow$ is used for phonological rules. The glosses given for the examples are those of the simple verb stem; no attempt is made to give the full range of pluractional meanings with each verb cited.

3. The shortening of the long vowel in the first syllable is due to an automatic vowel reduction rule in closed syllables.

4. Normally syllable-final $/ d /$ is realized as a rolled $/ \tilde{r} /$. This word is an unexplained exception.

5. As pointed out by Abubakar (1983/85), present-day Hausa $/ k w i i /, / g w i i /$, and $/ \mathcal{K}_{w i i} /$ reflect the diphthong / ui/ $(=/$ uy $)$.

6. The term "hyperpluractional" was suggested to me by Sammani Sani.

7. For an exactly parallel historical development in Oromo, a Cushitic language of Ethiopia, see Lloret (1988:167ff).

8. The synchronic CVG-formation rule easily accounts for the shape of pluractionals of "monoverbs" (simple CV verb roots), e.g. $b i \Rightarrow b i b b i$ 'follow', jaa $\Rightarrow$ jajjaa 'pull'. It doesn't, however, answer the question how these verbs formed their pluractionals when the suffixal rule was in effect. 


\section{REFERENCES}

Abubakar, Abdulhamid. 1983/85. Another look at Hausa diphthongs. Harsunan Nijeriya 13:120.

Al-Hassan, Belio S.Y. 1983. Intensivization: A study of the phonology and semantics of a category of Hausa reduplicants. M.A. thesis, Ahmadu Bello University [Zaria, Nigeria].

Faraclas, Nicholas, and Kay Williarnson. 1984. Assimilation, dissimilation and fusion: vowei quality and verbal reduplication in Lower Cross. Journal of African Languages and Linguistics $6: 1-18$.

Frajzyngier, Zygmunt. 1965. An analysis of intensive forms in Hausa verbs. Rocznik Orientalistyczny 29(2):31-51.

Gouffé, Claude, 1975. Redoublement et réduplication en haoussa: formes et fonctions. Bulletin de la Société de Linguistique de Paris 70(1):291-319.

Lloret, Maria-Rosa. 1988. Gemination and Vowel Length in Oromo Morphophonology. Ph.D. dissertation, Indiana University.

Newman, Paul. 1980. The Classification of Chadic within Afroasiatic. Leiden: Universitaire Pers.

1986a. Reduplicated nouns in Hausa. Journal of African Languages and Linguistics 8:115-32.

-1 1986b. Tone and affixation in Hausa. Studies in African Linguistics 17:249-67.

Parsons, F.W. 1981. Writings on Hausa Grammar. The Collected Papers of F.W. Parsons, 2 vols., ed. by G.L. Furniss. Ann Arbor: University Microfilms International.

Pawlak, Nina. 1975. The semantic problems of 'intensive' forms in Hausa verbs. Africana Bulletin [Warsaw] 23:139-49.

Department of Linguistics

Indiana University 